\title{
Southernmost records of Dromiciops gliroides: extending its distribution beyond the Valdivian rainforest
}

\section{Los registros más australes de Dromiciops gliroides: extendiendo su distribución más allá del bosque lluvioso valdiviano}

\section{Esteban Oda ${ }^{1}$, Gloria B. Rodríguez-Gómez ${ }^{2}$, Francisco E. Fontúrbel ${ }^{3}$, Mauricio Soto-Gamboa ${ }^{1}$ \& Roberto F. Nespolo ${ }^{1,4,5^{*}}$}

${ }^{1}$ Instituto de Ciencias Ambientales y Evolutivas, Facultad de Ciencias, Universidad Austral de Chile, Valdivia, Chile.

2Departamento de Ciencias Ecológicas, Facultad de Ciencias, Universidad de Chile, Santiago, Chile.

${ }^{3}$ Instituto de Biología, Facultad de Ciencias, Pontificia Universidad Católica de Valparaíso, Valparaíso, Chile. ORCID: 0000-0001-8585-2816

${ }^{4}$ Departamento de Ecología, Center of Applied Ecology and Sustainability (CAPES), Facultad de Ciencias, Pontificia Universidad Católica de Chile, Santiago, Chile.

${ }^{5}$ Millennium Institute of Integrative Biology (iBio), Santiago, Chile.

*Email: robertonespolorossi@gmail.com

\begin{abstract}
The geographic range of a species is often limited by sampling approaches, underestimating the actual distribution. This is likely the case of Dromiciops gliroides (Microbiotheria), an endemic marsupial from southern South America. We used camera-traps to record D. gliroides for the first time in Chaitén and Futaleufú (southern Chile), expanding its known distribution $100 \mathrm{~km}$ to the south. Climate and forest composition in this area differs from the typical Valdivian rainforest. Activity assessments show a narrow activity patterns compared to northern populations.
\end{abstract}

Keywords: activity patterns, camera traps, geography, Microbiotheria, temperate rainforest.

\section{RESUMEN}

El rango geográfico de una especie usualmente está limitado por el muestreo, subestimando su distribución. Este sería el caso de Dromiciops gliroides (Microbiotheria), un marsupial endémico de Sudamérica austral. Usamos cámaras-trampa para registrar a D. gliroides por primera vez en Chaitén y Futaleufú (al sur de Chile), expandiendo su distribución $100 \mathrm{~km}$ al sur. El clima y la composición del bosque de esta área difieren del bosque valdiviano. Los patrones de actividad encontrados son más estrechos que los de las poblaciones más al norte.

Palabras clave: bosque templado lluvioso, cámaras-trampa, geografía, Microbiotheria, patrones de actividad.

The geographic range of a species is a representation of the spatial arrangement of a given taxon, which defines the biological limits for its existence: it is the basic unit of biogeography (Brown et al. 1996). However, defining a distribution area could be challenging, as this inevitably depends on occurrence records and collecting methods, a requirement that could result in underestimations of the distribution areas due to lack of sampling effort and misconceptions about the species habits. Moreover, distribution limits dynamic boundaries that depend on resource availability and climate change (Anderson et al. 2009; Riquelme et al. 2018). This may be the case of Dromiciops gliroides (Thomas 1894, Microbiotheria), a relict marsupial that inhabits the temperate forests of Chile and Argentina in southern South America. This marsupial is considered a "living fossil" as it is the only living representative of Microbiotheria, the sister group of Australasian marsupials (Hershkovitz 1999; Mitchell et al. 2014). Several historical records of Dromiciops 
suggested relatively low population densities (Meserve et al. 1999; Kelt 2000), until the development of appropriate capturing methods that allowed a more frequent detection of this arboreal, nocturnal, and highly seasonal mammal (Muñoz-Pedreros et al. 2005; Fontúrbel \& Jiménez 2009; Fontúrbel 2010), which makes it a cryptic species. Most of the actual knowledge about $D$. gliroides comes from a few well-known sites, located in a small area at the center-south of the distributional range (Martin 2010).

Here we report the southernmost records of $D$. gliroides, which is beyond the limits of the Valdivian rainforest ecoregion in Chile. We set eight camera-traps (Bushnell Trophy Cam) from December 2018 to April 2019 along the Palena Province $\left(43^{\circ}\right.$ $24^{\prime} \mathrm{S}, 72^{\circ} 05^{\prime} \mathrm{W}$; $43^{\circ} 25^{\prime} \mathrm{S}, 72^{\circ} 12^{\prime} \mathrm{W}$ and $43^{\circ} 00^{\prime} \mathrm{S}, 72^{\circ} 28^{\prime} \mathrm{S}$ ), southern Chile. We found 43 photographic records at Chaitén and Futaleufú (Fig. 1), extending D. gliroides distribution 100 $\mathrm{km}$ to the south (Fig. 2). The current distribution area of $D$. gliroides is based on 20 locations (Patterson et al. 2003), but in more recent reports, Martin (2010) of and (Gurovich et al. 2015) provided 69 additional occurrence locations, which fall within NatureServe's distribution map (except for one location at the north). Our study provides six new points, from which three are located southwards of the known distribution. By extending $D$. gliroides distribution based on this new data, it has increased $4969 \mathrm{~km}^{2}$. In sympatry with $D$. gliroides, we detected nocturnal activity of two rodents species (Oligoryzomys longicaudatus and Rattus spp.) along with several birds species (Pteroptochos tarnii, Scelorchilus rubecula and Campephilus magellanicus as the most frequent ones).

We also examined $D$. gliroides activity patterns at the new locations (Fig. 3a), using the activity package (Rowcliffe 2019) in R 3.5.3 (R Development Core Team 2019). Activity starts at $19 \mathrm{~h}$ and ends at $7 \mathrm{~h}$, being similar to the activity patterns previously reported for the Valdivian rainforest (Fontúrbel et al. 2014) but showing a narrower activity peak (Fig. 3b). We contrasted the activity patterns of Fontúrbel et al. (2014) against the pattern obtained here using the compareCkern function of the activity package, with 1000 permutations. We found an overlap of $82.45 \pm 0.04 \%$ between both activity patterns, but the differences were marginally significant $(P=0.053)$.
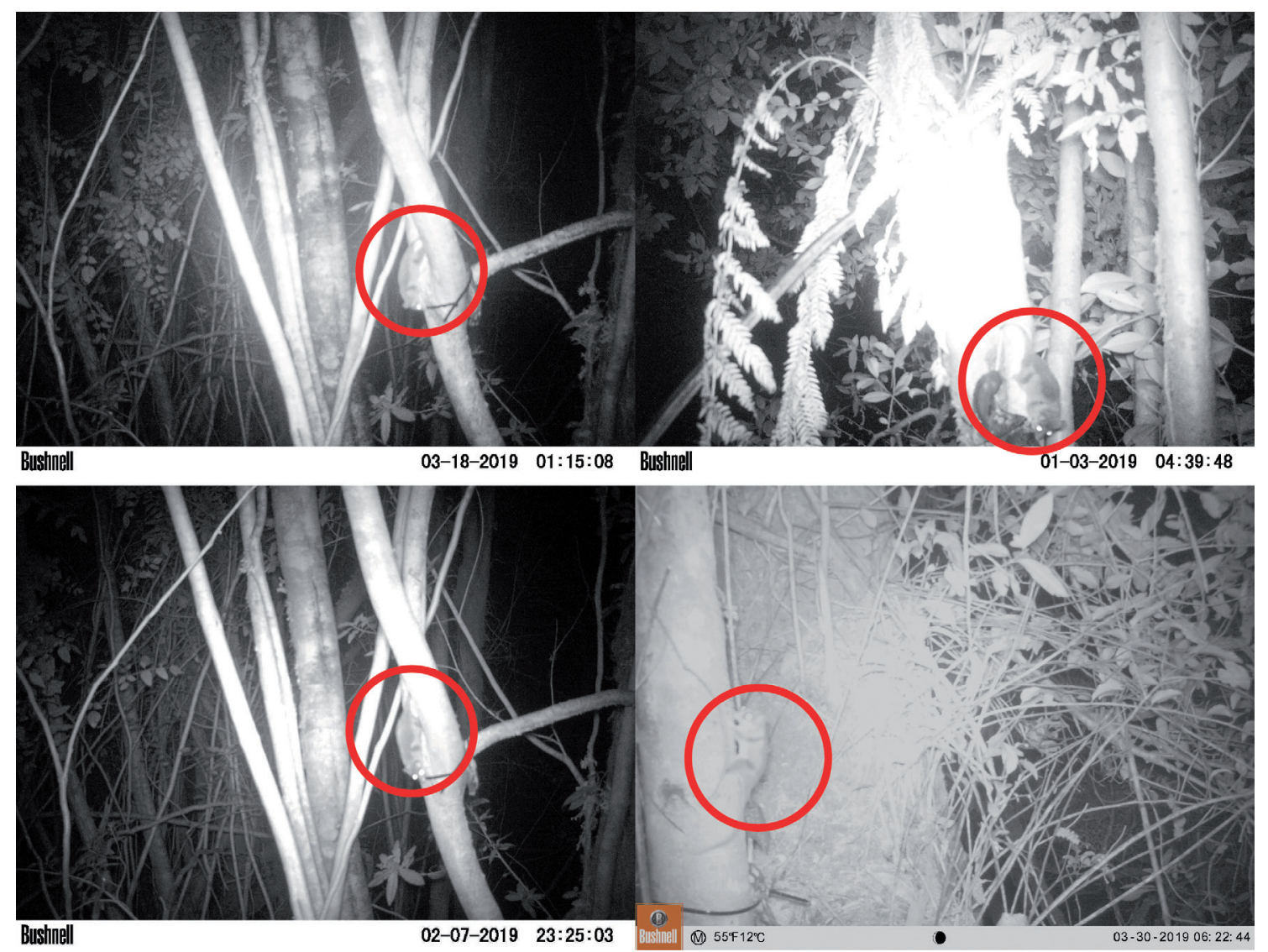

Figure 1. Camera trap records of Dromiciops gliroides at Chaitén and Futaleufú. / Registros de Dromiciops gliroides en cámaras trampa de Chaitén y Futaleufú. 


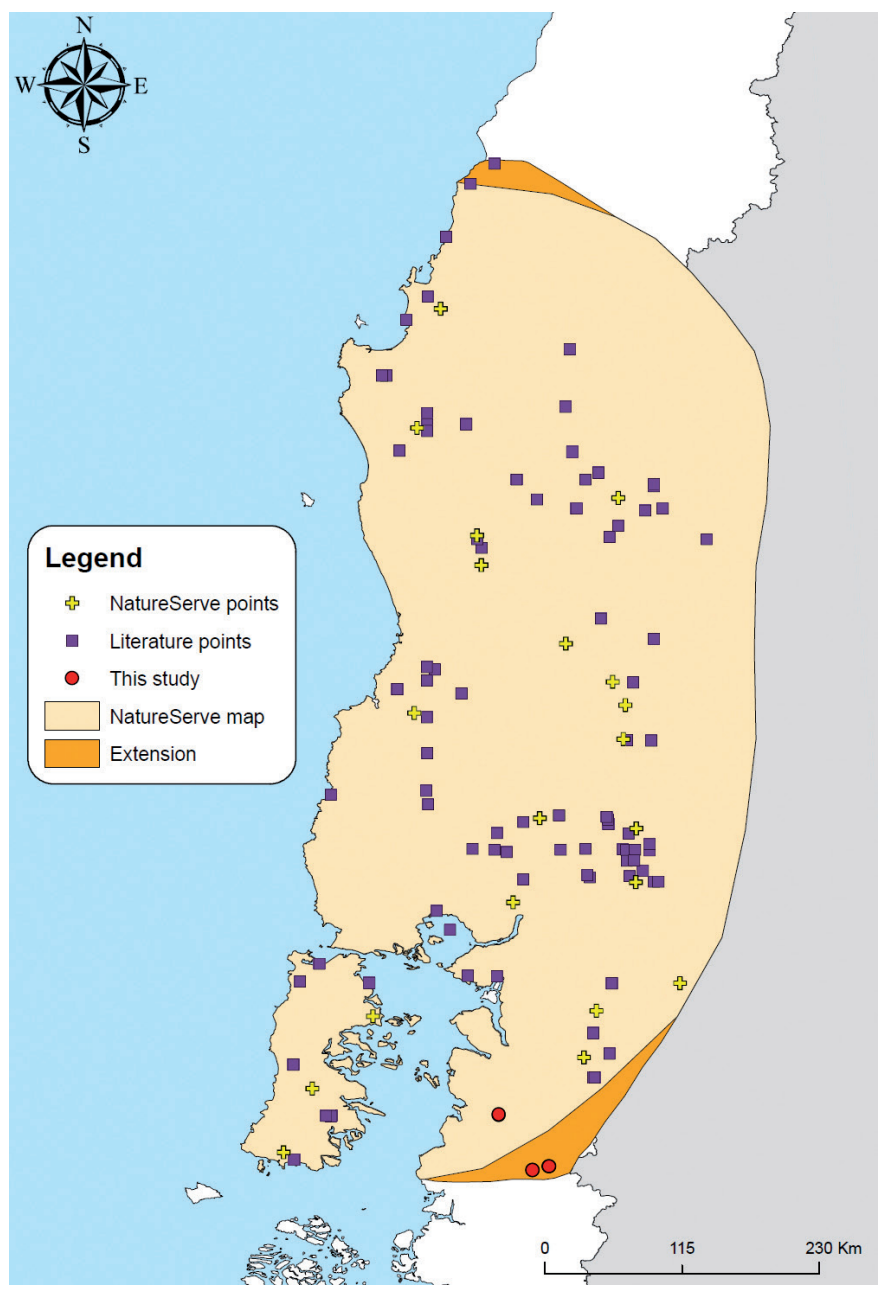

FIGURE 2. Distribution map of Dromiciops gliroides, comparing the current and proposed extension areas. / Mapa de distribución de Dromiciops gliroides, comparando la distribución actual y la extensión propuesta.

The ecological patterns of $D$. gliroides are quite consistent across the Valdivian rainforest, showing similar home ranges, body condition and population densities among sites of Argentina and Chile (Fontúrbel et al. 2012). However, we do not know how $D$. gliroides may respond to environmental conditions southwards of the Valdivian temperate rainforest, where there are larger daily and seasonal temperature fluctuations, lower rainfall, and colder nights that may trigger hibernation responses (Nespolo et al. 2018), narrowing their activity patterns. Also, we found differences in the forest composition. Some plant species that are typically associated with $D$. gliroides are less frequent or inexistent at this southernmost latitude. Such is the case of the bamboo Chusquea spp., one of the main components of $D$. gliroides nests and an important

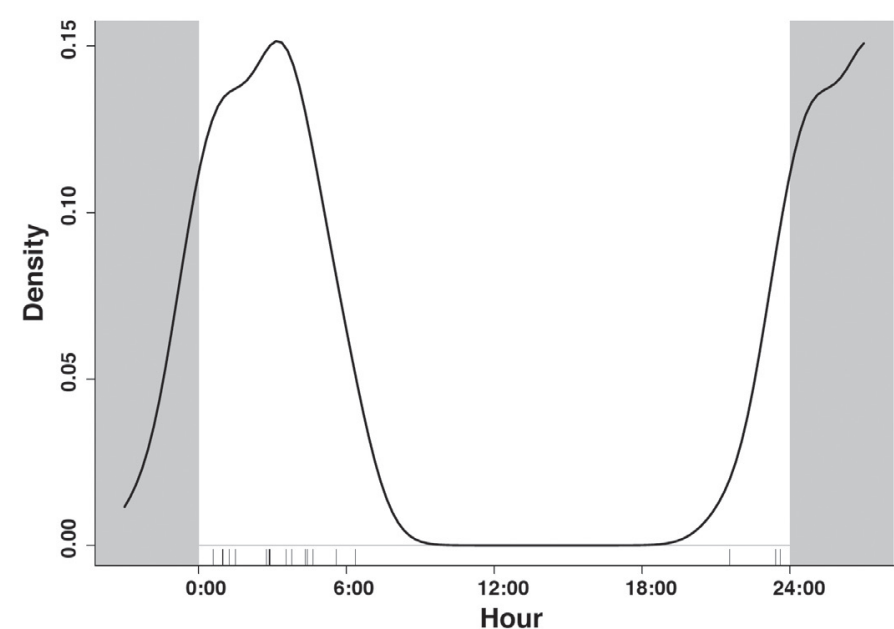

FIGURE 3. Kernel density functions of Dromiciops gliroides activity for (a) Chaitén-Futaleufú, and (b) the comparison of the Valdivian temperate rainforest and the Chaitén-Futaleufú. / Función de densidad de kernel de la actividad de Dromiciops gliroides en: (a) Chaitén-Futaleufú, y (b) la comparación de la selva lluviosa Valdviana y Chaitén-Futaleufú.

predictor of its presence (Rodríguez-Cabal \& Branch 2011), which is considerably less frequent in the newly discovered sites than in the Valdivian ecoregion (González \& Donoso 1999). Another example is the hemiparasitic mistletoe Tristerix corymbosus, which constitutes a substantial part of $D$. gliroides diet (Amico \& Aizen 2000; Amico et al. 2009), is not present in the Chaitén-Futaleufú region. Those individuals may be feeding on the fleshy-fruited shrub Ugni molinae, which is highly abundant in these new locations (Mora \& Soto-Gamboa 2011), and might be explaining its persistence below T. corymbosus' distribution. These differences may alter resource availability for $D$. gliroides, consequently changing its diet and metabolic requirements (Cortés et al. 2011) in ways that are yet to be explored.

Except for the disturbance events of volcanic eruptions of the Chaitén volcano, the overall environmental conditions of the forest area surrounding the newly found $D$. gliroides locations have been stable at least since the Holocene (Heusser et al. 1992; Amico et al. 2009; Swanson et al. 2013). Therefore, the presence of $D$. gliroides in this area may not be recent, and the lack of other reports would be a consequence of insufficient sampling efforts. We strongly encourage further assessments of this iconic species of the Chilean fauna beyond the southern limit reported here, which is highly likely. In this sense, camera traps are a powerful approach to expand our knowledge of cryptic species. 


\section{ACKNOWLEDGEMENTS}

We thank Jonathan Vergara, Carolina Contreras and Sebastian Flores for their field assistance. This study was funded by FONDECYT grant 1180917 for RFN. FEF was supported by FONDECYT grant 11160152.

\section{REFERENCES}

Amico, G.C., Aizen, M.A. 2000. Mistletoe seed dispersal by a marsupial. Nature 408: 929-930.

Amico, G.C., Rodríguez-Cabal, M.A., Aizen, M.A. 2009. The potential key seed-dispersing role of the arboreal marsupial Dromiciops gliroides. Acta Oecologica 35: 8-13.

Anderson, B.J., Akçakaya, H.R., Araujo, M.B., Fordham, D.A., Martinez-Meyer, E., Thuiller, W., Brook, B.W. 2009. Dynamics of range margins for metapopulations under climate change. Proceedings of the Royal Society B-Biological Sciences 276: 1415-1420.

Brown, J.H., Stevens, G.C., Kaufman, D.M. 1996. The geographic range: Size, shape, boundaries, and internal structure. Annual Review of Ecology and Systematics 27: 597-623.

Cortés, P.A., Franco, M., Sabat, P., Quijano, S.A., Nespolo, R.F. 2011. Bioenergetics and intestinal phenotypic flexibility in the microbiotherid marsupial (Dromiciops gliroides) from the temperate forest in South America. Comparative Biochemistry and Physiology a-Molecular \& Integrative Physiology 160: 117-124.

Fontúrbel, F.E., Jiménez, J.E. 2009. Underestimation of abundances of the Monito del Monte (Dromiciops gliroides) due to a sampling artifact. Journal of Mammalogy 90: 1357-1362.

Fontúrbel, F.E. 2010. A methodological approach to assess the small mammal community diversity in the temperate rainforest of Patagonia. Mammalian Biology 75: 294-301.

Fontúrbel, F.E., Franco, M., Rodríguez-Cabal, M.A., Rivarola, M.D., Amico, G.C. 2012. Ecological consistency across space: a synthesis of the ecological aspects of Dromiciops gliroides in Argentina and Chile. Naturwissenschaften 99: 873-881.

Fontúrbel, F.E., Candia, A.B., Botto-Mahan, C. 2014. Nocturnal activity patterns of the monito del monte (Dromiciops gliroides) in native and exotic habitats. Journal of Mammalogy 95: 1199-1206.

González, M.E., Donoso, C. 1999. Seed and litter fall in Chusquea quila (Poaceae: Bambosoideae), after synchronous flowering in south-central Chile. Revista Chilena de Historia Natural 72: 169-180.

Gurovich, Y., Stannard, H.J., Old, J.M. 2015. The presence of the marsupial Dromiciops gliroides in Parque Nacional Los Alerces, Chubut, Southern Argentina, after the synchronous maturation and flowering of native bamboo and subsequent rodent irruption. Revista Chilena De Historia Natural 88: art17.

Hershkovitz, P. 1999. Dromiciops gliroides Thomas, 1894, last of the Microbiotheria (Marsupialia), with a review of the family Microbiotheriidae. Fieldiana Zoology 93: 1-60.

Heusser, C.J., Huesser, L.E., Hauser, A. 1992. Paleoecology of Late Quaternary deposits in Chiloé continental, Chile. Revista Chilena de Historia Natural 65: 235-245.

Kelt, D.A. 2000. Small mammal communities in rainforest fragments in central southern Chile. Biological Conservation 92: 345-358.

Martin, G.M. 2010. Geographic distribution and historical occurrence of Dromiciops gliroides Thomas (Metatheria: Microbiotheria). Journal of Mammalogy 91: 1025-1035.

Meserve, P.L., Martínez, D.R., Rau, J.R., Murúa, R., Lang, B.K., Muñoz-Pedreros, A. 1999. Comparative demography and diversity of small mammals in precordilleran temperate rainforests of southern Chile. Journal of Mammalogy 80: 880-890.

Mitchell, K.J., Pratt, R.C., Watson, L.N., Gibb, G.C., Llamas, B., Kasper, M., Edson, J., Hopwood, B., Male, D., Armstrong, K.N., Meyer, M., Hofreiter, M., Austin, J., Donnellan, S.C., Lee, M.S.Y., Phillips, M.J., Cooper, A. 2014. Molecular phylogeny, biogeography, and habitat preference Evolution of Marsupials. Molecular Biology and Evolution 31: 2322-2330.

Mora, J.P., Soto-Gamboa, M. 2011. Legitimate seed dispersal Ugni molinae Turcz. (Myrtaceae), by monito del monte, Dromiciops gliroides. Gayana Botanica 68: 309-312.

Muñoz-Pedreros, A., Lang, B.K., Bretos, M., Meserve, P.L. 2005. Reproduction and development of Dromiciops gliroides (Marsupialia: Microbiotheriidae) in temperate rainforests of Southern Chile. Gayana 69: 225-233.

Nespolo, R.F., Gaitan-Espitia, J.D., Quintero-Galvis, J.F., Fernandez, F.V., Silva, A.X., Molina, C., Storey, K.B., Bozinovic, F. 2018. A functional transcriptomic analysis in the relict marsupial Dromiciops gliroides reveals adaptive regulation of protective functions during hibernation. Molecular Ecology 27: 4489-4500.

Patterson, B.D., Ceballos, G., Sechrest, W., Tognelli, M.F., Brooks, T., Luna, L., Ortega, P., Salazar, I., Young, B.E. 2003. Distribution maps of the mammals of the western hemisphere. NatureServe, Arlington VA. 9 pp.

R Development Core Team. 2019. R: A language and environment for statistical computing, reference index version 3.5.3. Vienna, Austria: Foundation for Statistical Computing.

Riquelme, C., Estay, S.A., Lopez, R., Pastore, H., Soto-Gamboa, 
M., Corti, P. 2018. Protected areas' effectiveness under climate change: a latitudinal distribution projection of an endangered mountain ungulate along the Andes Range. PeerJ 6: e5222.

Rodríguez-Cabal, M.A., Branch, L.C. 2011. Influence of habitat factors on the distribution and abundance of a marsupial seed disperser. Journal of Mammalogy 92: 1245-1252.
Rowcliffe, M. 2019. activity: Animal Activity Statistics. R package version 1.2. https://CRAN.R-project.org/ package=activitypp

Swanson, F.J., Jones, J.A., Crisafulli, C.M., Lara, A. 2013. Effects of volcanic and hydrologic processes on forest vegetation: Chaitén Volcano, Chile. Andean Geology 40: 359-391.

Received: 25.06 .2019

Accepted: 06.12.2019 